\title{
Mehmet Asaf'ın Bihterle Muhlis Adı Hikâyesi ve İncelemesi
}

\author{
Mehmet Asaf's Story and Investigation of Bihter and Muhlis \\ Mehmet SOĞUKÖMEROĞULLARI ${ }^{*}$
}

$\ddot{O} \mathbf{z}$

\begin{abstract}
Birçok türde eserleri olan Mehmet Asaf' ın inceleme konumuz olan Bihter'le Muhlis adlı hikâyesi Bihter ve Muhlis adlı iki gencin çocuk yaşta birbirlerini sevmeleri, nişanlanmaları, ancak evlenememeleri üzerine kuruludur. Eser sekiz metin halkasından oluşur ve düz bir çizgi üzerinde ilerlediği için klasik hikâye formundadır. Açık mekânların daha çok tercih edildiği metnin başlangıcı İstanbul'da, sonu ise Bursa'da geçer. Zaman unsuruna eserde yer verilmez. Ancak dolaylı olarak kolera salgını ve Hocapaşa Yangını dolayısıyla okuyucunun zamanı çıkarması beklenir. Şahıslar kadrosu oldukça geniş olmasına rağmen Bihter ve Muhlis dışında hakkında bilgi verilen şahıs yoktur. Metnin dili bazı yerlerde sade, bazı yerlerde ise ağdalıdır. Kullanılan izlekler, aşk, âfet, kalıtım, salgın ve müzik kültürüdür.
\end{abstract}

Anahtar Kelimeler: Mehmet Asaf, Bihter'le Muhlis, Yapı.

\section{Abstract}

The story of Mehmet Asaf, who has works in many genres, named Bihter and Muhlis, which is the subject of our study, is based on the fact that two young people, Bihter and Muhlis, loved each other at an early age, got engaged, but could not get married. The work consists of eight text circles and is in the form of a classic story as it proceeds on a straight line. The beginning of the text, in which open spaces are more preferred, takes place in Istanbul and ends in Bursa. The time element is not included in the work. However, indirectly, the reader is expected to take the time due to the cholera epidemic and Hocapaşa Fire. Although the staff is quite large, there is no person other than Bihter and Muhlis, about whom information is given. The language of the text is plain in some places and slick in others. The themes used are love, disaster, heredity, epidemic and music culture.

Keywords: Mehmet Asaf, Bihter'le Muhlis, Structure.

\section{Giriş}

Mehmet Asaf' $1 n^{1}$ eserlerinden biri ve makalenin ana metni olan Bihter'le Muhlis adlı hikâyenin yayınlanma tarihi belli değildir. Ancak eser Osmanlı Türkçesiyle yayınlandığı için 1928 'den önce yazıldığına hükmedilebilir. Eserin olay örgüsü Muhlis ve Bihter'in küçük yaşta birbirlerini sevmeleri, ancak evlenememeleri üzerine kuruludur. Eserin zamanı1890'lı yıllara rastlar; mekân ise İstanbul'da başlayıp Bursa'da biter. Metnin geneline aşk duygusu hâkimdir. Şahıs kadrosu metnin türünden kaynaklı olarak dar tutulmuştur. İzlekler ise, çok geniş bir yer tutmaz. Makalenin amacı kısaca tanıtımı yapılan metni çeviriyazı ile neşretmek ve hikâyeyi çözümlemektir.

\section{Olay Örgüsü}

Mehmet Asaf'in Bihter Muhlis adlı hikâyesi bir sünnet düğünü ile başlar. Sünnet düğününde henüz sekiz dokuz yaşındayken Bihter'i gören Muhlis ona âşık olur. $O$ yıllarda Muhlis ve Bihter'in babası da bu birlikteliği uygun gördüklerini ve zamana bıraktıklarını ifade ederler. Muhlis on üç yaşında iken rüştiyeyi bitirerek idadiye geçer ve burada edebiyata merakı artar. Muallim Naci'yi çok beğenen Muhlis'in yanı sıra Bihter'in de edebiyata merakı vardır. Bihter'in edebiyata merakını gören babası, Muhlis'in babasından onun Bihter'e bazı geceler edebiyatın kaidelerini anlatmasını rica eder. Muhlis'in babası bunu münasip görür.

\footnotetext{
* Doç. Dr., Gaziantep Üniversitesi, Fen Edebiyat Fakültesi, Türk Dili ve Edebiyatı Bölümü, magcan1982@gmail.com

${ }^{1}$ Mehmet Asaf'ın hayatı ile ilgili olarak bk. Münir Süleyman Çapanoğlu, (1961). Seksen yıllık gazetecimiz âsaf konsilitçi. İstanbul: Sinan Matbaası; Mehmet Nuri İnuğur (1999). Türk basınında “iz” birakanlar, İstanbul: Der Yayınları; Müjgan Cunbur (2002). Borsacı, mehmet asaf. Türk Dünyası Ortak Edebiyatı Türk Dünyası Edebiyatçıları Ansiklopedisi. , C. 2. s. 316-317; İhsan Işık, (2007). Resimli ve metin örnekli türkiye edebiyatçılar ve kültür adamları ansiklopedisi. (2. Cilt). Ankara: Elvan Yayınları; Mehmet Soğukömeroğulları, "Mehmet Asaf Borsacı", Türk Edebiyatı Ísimler Sözlüğ̈̈, 28.03.2019.
} 
Muhlis'le Bihter'in müzik ve edebiyat icra ettikleri gecelerde her ikisi de șiirlerini okur ve müzik icra eder. Ancak Bihter'in babasının Bursa'ya tayininin çıkması üzerine Bihter'i yolcu etmek üzere rıhtıma giden Muhlis ve ailesi onları gemiye kadar bindirir. Bu sırada Muhlis Bihter'e kendisini unutmaması için fotoğrafını verir.

Muhlis, okul arkadaşı Şevket'e Bihter'le olan ilişkilerini anlatır. Şevket ona Bursa'nın yakın bir yer olduğunu kısa sürede oraya gidebileceğini söyler. Okulu bitirdikten sonra Şevket Bursa'ya, Muhlis ise İstanbul'a tayin edilir. Uzun bir süre görüşmezler ve hastalanan Muhlis doktor tavsiyesi üzerine Bursa'ya kaplıcalara gitmek zorunda kalır. Bursa'da trenden indiği sırada arkasından Şevket onu çağırır ve evine götürür. Onun evine gittiklerinde Şevket'in kızı Sara ile karşılaşan Muhlis'in çocukta tanıdık bir sima görmesi üzerine Şevket'ten Bihter'le evlendiğini öğrenir. O gece orada misafir olarak kalan Muhlis, ertesi gün yatağının üzerinde sararmış bir fotoğraf bulur ve fotoğraftakinin kendisi olduğunu anlar. Böylece on sekiz sene önce beslediği aşkın reddedildiğini fark eder.

Hikayenin vaka birimleri şu şekildedir:

1. Sünnet dügününde Bihter'le Muhlis'in birbirlerini görmesi ve Muhlis'in Bihter'i istemesi.

2. Muhlis'le Bihter'in edebiyata merakının başlaması ve Muhlis'in Bihter'e edebiyat dersleri vermesi.

3. Bihter'in babasının Bursa'ya tayini çıkması ve giderlerken Muhlis'in fotoğrafını Bihter'e vermesi.

4. Muhlis'in aşkını Şevket'e anlatması ve okulu bitirdikten sonra Şevket'in Bursa'ya, Muhlis'in İstanbul'a tayininin çıkması.

5. Muhlis'in hastalanması ve doktorların isteği üzerine Bursa'ya kaplıcaya gitmesi.

6. Bursa' da Şevket'le karşılaşması ve Şevket'in evine misafirliğe gitmesi.

7. Şevket'ten Bihter'le evlendiğini öğrenmesi.

8. Bihter'in on sekiz yıl önceki fotoğrafını yatağının üzerine bıraktığını görerek reddedildiğini anlaması.

Sekiz metin halkasından oluşan metnin 1. ve 2. metin halkaları eserin giriş mahiyetinde kaleme alınmıştır. Merak unsuru 3. metin halkasında başlar. Buna göre 3, 4, 5, 6 metnin gelişme bölümüdür ve merak unsuru üst düzeye çıkarılmıştır. 7. ve 8 . metin halkaları düğümün çözüldüğü ve Muhlis' in reddedildiğini öğrendiği bölümlerdir. Bu tür metinler İsmail Çetişli'ye göre "tek zincirli olay örgüsü” şeklinde tanımlanır (Çetişli, 2004: 32). Metnin baştan başlatma metoduyla kurgulanan (Çetin, 2005: 190) küçük bir aşk hikâyesi olmasına, olayın düz bir çizgide ilerlemesine ve olay unsurunu öncelemesine (Çetin, 2017: 17) bağlı olarak klasik hikâye olduğuna hükmedilir.

\section{Anlatıcı ve Bakış Açısı}

Metinde "nesnel tutumlu gözlemci anlatıcı" kullanılır. Metnin ilk paragrafında bunu hissetmek mümkündür.

"Evin içi kalabalık mı kalabalık...Sinekli Bakkal'dan halesi, Çapa Çeşmesi'nden teyzesi, Gedikpaşa'dan büyük ablası, Kabasakal'dan anneannesi, Zirek'ten ebesi, Kara Gümrük'ten eski aşçı kadın, Yeni Bahçe'den kahveciye verdikleri besleme, Kırkçeşme'den komşunun azatlısı Tarandil bugün hep buraya toplanmışlar..." (s. 2).

Yukarıdaki örnekte anlatıcının olayları gözlemlediği ve bunu nesnel bir şekilde yaptığı net olarak görülür. Bulunduğu sünnet dügününde kişileri gözlemler ve onların aklından geçenleri dikkate almayarak sadece gözlemlerini nesnel bir şekilde anlatmaya çalışır. Buna bağlı olarak gözlemci figürün bakışıyla kaleme alınan metinde hikâyenin unsurları olan mekân, zaman, olay, ve şahıs kadrosu onun bakış açısıyla okuyucuya sunulur. 


\section{Mekân}

Olayın yoğun olarak işlenmesine bağlı olarak hikâyede açık ve kapalı mekânlar genel olarak tasvirlerine girilmeden isim olarak verilmiştir. Hikâyenin önemli bir bölümü İstanbul'da geçer. İstanbul'un semtlerinden Sarıyer, Boğaziçi, Kadıköy, Haydarpaşa, Sinekli Bakkal, Çapa Çeşmesi, Gedikpaşa, Kabasakak, Zirek, Kara Gümrük, Yeni Bahçe, Kırk Çeşme metinde isim olarak geçen mekânlardır. Ayrıca Muhlis'in Bihter'i yolcu etmek için Galata rıhtımına gitmeleriyle birlikte kendine yer bulan Galata Rıhtımı metinde geçen İstanbul'la ilgili mekânlardandır. Galata Rıhtımı'nın fiziksel tasviri metinde yer almamasına rağmen yolcuların çok olduğu ve hamalların yük taşıdıkları vesilesiyle kısa bir tanıtıcı bölüm yer alır. Bihter'in babasının tayininin Bursa'ya çıkmasıyla birlikte İstanbul dışında ikinci bir il de mekân olarak kullanılır. Muhlis'in arkadaşı Şevket, Muhlis'e Bursa yolunu tarif ederken Mudanya'dan gidildiğini ve tren kullanıldığını ifade eder. Ayrıca Bursa'nın İstanbul'un bir mahallesi olduğunu ve Sarıyer'e gitmek gibi gidildiğini de ifade ederek yakınlığını vurgular. Metinde Bursa, Muhlis'in oraya hastalığı sebebiyle yeniden gidişi üzerine tekrar metne dâhil olur. Bursa'ya giderken arkadaşı Şevket'in dediği güzergâhtan Bursa'ya ulaşır. Bursa bu defa Çekirge ilçesi ve kaplıcalarıyla tanıtılır. Çekirge'deki Acemler İstasyonu da Muhlis'in orada trenden inmesiyle isim olarak geçer. Yolculuğunu anlatırken her iki tarafin zeytin ağaçları ile dolu olduğunu da belirtir. Acemler İstasyonu'nda arkadaşı Şevket'le karşılaşan Muhlis, onun tayin yerlerini öğrenmesine bağlı olarak İzmir ve Konya da isim olarak hikâyeye dâhil olur.

Hikâyede kapalı mekânlar da çok fazla detay verilmeden kullanılır. İlk mekân sünnet düğ̈nü yapılan evdir. Buranın kalabalık olması dışında tasvirine yer verilmemiştir. Metindeki diğer mekân Bihter'in İstanbul'daki evidir. Bu ev hakkında da metinde bilgi verilmez. Sadece Bihter'in şiir okumak için içerideki odadan gelmesi evde birden çok oda olduğuna delalet eder. En son mekân ise, Bihter ile Şevket'in Bursa'daki evidir. Ev hakkında hiçbir bilgi verilmez. Ancak Muhlis'in burada kaldığ 1 oda isim olarak kullanılır.

\section{Zaman}

Hikâyede nesnel zaman ile ilgili net bir bilgi verilmez. Ancak iki önemli tarihî olaya gönderme yapılarak metnin zamanı hakkında okuyucu fikir sahibi edilir. Bunlardan ilki İstanbul'daki büyük kolera salgınıdır. İstanbul'daki kolera salgını 1831'de başlamış ve uzun yıllar devam etmiştir (Özdemir, 2019, s. 27). Bu bilginin ardından Hocapaşa Yangınının olmadığı dönemlerde geçtiği bilgisi verilir (s. 5). Hocapaşa yangınının tarihi 1865 'tir (Gürses Söğüt, 2019, s. 54-59). Muhlis' in babasının gönül ilişskisi bu tarihlere rastlar. Olay da bu tarihten 25-30 yıl sonrasında geçer. Buna göre metnin nesnel zamanının başlangıcı 1890'lı yıllara tekabül eder ki Muhlis bu yıllarda 8 yaşındadır. Metnin ikinci bilgi verilen kısmı Muhlis'in 14 yaşında Bihter'e müzik dersi vermeye başlamasıdır. Hikâyenin sonunda ise bu tarihten 15 yıl geçmiş ve Muhlis Bursa'ya gitmiştir. Buna göre metin 1890'l yıllarda başlamış 1920'li yıllarda son bulmuştur. Başka bir deyişle otuz yıllık bir zaman diliminde geçer. Ayrıca Bursa' ya gittiği dönem bahar mevsimi ve nisan ayı sonudur.

Nesnel zaman haricinde hikâyenin Bihter ve Muhlis'in çocukluğuyla başlayıp, birbirlerine âşı olmaları ve kendilerine farklı yollar çizmeleri çevresinde ilerlediği için zaman unsuru bu iki şahsın yaşam evrelerine göre şekillenen biyografik bir sürecin zamana uyarlanan izdüşümüdür. Çünkü metnin süreci takip edildiğinde Muhlis'in sünnet dügünüyle başlayıp Bihter'e âşık olması ve Bihter'den ayrılmaları şeklinde bir zaman eğrisinin mevcut olduğu görülür. Ayrıca Muhlis'in Bihter'in evine gidiş süreci olan 1 hafta veya on gün, Bursa'ya gidiş süresi olan on beş yıl sonra ve Bursa'ya yolculuğu olan dört buçuk saat hep aynı anlayışın tezahürüdür. 

olmasidir

Metinde zamanla ilgili diğer dikkat çeken nokta net tarihlerin bazen verilmemiş

"Geçmiş gün... Yirmi beş senelik bir şey.. Belki de otuz.. Büyük koleradan evvel miydi, sonra mıydı bilmem? Hocapaşa yangını o zaman galiba daha olmamıştı." (s. 5).

"Bu geceden sonra hemen bir hafta kadar Muhlis'le Bihter birbirlerini görmemişlerdi. Bir hafta, belki on gün sonra bir gece yine ailesiyle beraber Muhlislerin evine gelen Bihter; gayet endişeli bir tavır ile:" (s. 16).

Ancak hikâye kişilerinin yaşları ve yaşlarının ilerlediği dönemlerde verilen tarihler oldukça nettir. "Muhlis'in on sekiz sene evvel gözyaşlarlyla beslediği aşk-ı masumanesi on sekiz sene sonra işte böyle iade olunmuş, reddedilmişti.” (s. 24) örnekte bu daha net görülür.

\section{Şahıs Kadrosu}

Kurmaca eserlerde, olayın meydana gelmesinde etken rol üstlenen insan veya inşan vasfı kazanmış varlıklar veya kavramlar "şahıs kadrosu”nu oluştururlar (Aktaş, 2015, s. 43). Bihter'le Muhlis adlı hikâyenin şahıs kadrosu Muhlis, Bihter ve fon veya dekoratif kişilerden oluşur.

\section{Muhlis}

Muhlis'in sekiz yaşında sünnet olmasıyla hikâye başlar. Sünnet düğününde Bihter'i gören Muhlis ona âşık olur. Babası Zekâi Efendi'dir. On üç yaşında rüştiyeyi bitiren Muhlis idadiye geçer. $\mathrm{Bu}$ yıllarda şiire yakınlığı başlayan Muhlis'in en sevdiği sanatçılar Nedim, Fuzuli, Muallim Naci, Nuri, Şeyda, Andelib, Müstecabizade İsmet, Andelib, Mehmet Celal ve Muhyiddin'dir. Aruzu öğrenmiş ve edebiyat kurallarını okumuştur. Kendisi de çeşitli şiirler kaleme almaktadır. Bu alanda oldukça ilerlediği için Bihter'in babası ondan kızına edebiyat dersleri vermesini rica eder. Bihter'e olan sevgisi bitmeyen Muhlis, o Bursa'ya giderken ona fotoğrafını verir. Fakat tekrar onun peşinden gitmez. Bunu da utangaç ya da sevdiğinin peşinden gitmeyen bir kişi olarak yorumlamak mümkündür. Kendi iç dünyasını fazla dışarıya veremeyen bir kişi olan Muhlis'in bu sevdasından sadece arkadaşı Şevket'in haberi vardır. Başka bir deyişle bu düşüncesini sadece Şevket'e söyler. Bu da onun içe kapanık bir kişi olduğuna delalet eder. Okulu bittikten sonra İstanbul'da bir memuriyete tayin edilir, bir taraftan da edebiyatla meşgul olur. Metnin sonlarına doğru yakalandığı bir hastalık dolayısıyla zayıfladığı hakkında bilgi verilir. $\mathrm{Bu}$ dönemlerde metnin ilerleyişine bağlı olarak otuz bir yaşında olduğuna hükmedilir. Söz konusu hastalık dolayısıyla Bursa'ya yalnız gitmesine bağlı olarak evlenmediği gözlemlenir. Metnin sonunda sevdiği kızın en yakın arkadaşıyla evlenmesi ve yatağına 18 yıl önce verdiği fotoğrafı bırakmasını aşkının reddedilmesi olarak algılaması da hikâye kişisinin kendisinde hiç suç bulmadığı anlamına gelir ki içe kapanık kişi özelliği olarak söz konusu durumu yorumlamak gerekir. Muhlis'in fiziksel özellikleri ile ilgili metinde herhangi bir bilgi verilmez.

\section{Bihter}

Muhlis'in sünnet düğününde altı yaşındadır. Onunla ilgili verilen fiziksel tasviri göre kara gözlüdür. Babası Arif Bey'dir. Muhlis idadiye geçtiği sıralarda edebiyat sahasında okuduğu anlar bir seviyededir. Şiir yazmakta, ut çalmaktadır. Şevket'le Bursa'da evlenmiş 12 yaşında Sara adında bir kızı olmuştur. On sekiz yıl sonra Muhlis'in verdiği fotoğrafı tekrar ona iade etmesi Muhlis'i suçlamak veya eleştirmek içindir. Çünkü Şevket Bursa, Konya ve İzmir'de çalışıp Bursa'ya yeniden tayin olduktan sonra evlenmişlerdir ve o zamana kadar Muhlis'i beklemiştir. 


\section{Fon / dekoratif kişiler}

Metinde olay genel olarak Bihter ve Muhlis çevresinde cereyan eder. Eserde birçok kişi olmasına rağmen bunlar ya sadece isim olarak geçerler ya da çok kısa bilgilerle onlar hakkında okuyucu haberdar edilir.

Evin içi kalabalık mı kalabalık...Sinekli Bakkal'dan halesi, Çapa Çeşmesi'nden teyzesi, Gedikpaşa'dan büyük ablası, Kabasakal'dan anneannesi, Zirek'ten ebesi, Kara Gümrük'ten eski aşçı kadın, Yeni Bahçe'den kahveciye verdikleri besleme, Kırkçeşme'den komşunun azatlısı Tarandil bugün hep buraya toplanmişlar...

Bunlara Muhasebecilerin hanımı iki kızıyla, Alperdelilerin hanımı beş yaşındaki torunuyla, Defterdarların gelinini iki çocuğu bir hizmetçisiyle, Yağlıkçıların kaynanasını kız kardeşiyle, Mısırçarşılıların annesini gelini ile, yandaki, karşıdaki, alt ve üst taraftaki komşuları, uzaktan yakından, Boğaziçi’nden, Kadıköy ve Haydarpaşa'dan gelenleri bütün büyüğü, küçüğü, ortancası, çocuğu, görümcesi, kaynanası, baldızı, kızı, torunu, hizmetçisi, beslemesi ile ilave edecek olursanız evin ne derecede izdiham içinde olduğu derhâl tezahür eder. Gürültü, patırtı mı dediniz? Haddi, hesabı yok. Sadanın, zırıltının, vizıltının envaı: (s. 2-3).

Muhlis'in ninesi, annesi, Bihter'in annesi ve babası Zekâi Efendi metinde isim olarak kişilerdir. Muhlis'in idadiden arkadaşı Şevket de Bihter'le evlenmesi dolayısıyla hakkında diğerlerinden biraz fazla bilgi verilen kişilerden biri olur. İdadiden sonra Bursa, Konya, İzmir ve Konya'da çalışan Şevket, Muhlis'in dert ortağıdır ve Muhlis Bihter'e aşkını ona itiraf etmesine rağmen Bihter'le evlenmiştir. Bursa'da oturmaktadır.

Metinde gençliğiyle ilgili bilgi verilen tek kişi Muhlis'in babası Arif Bey'dir. Buna göre, Arif Bey, on beş yaşında tiyatrolara gitmekte, kantocu kızlara çiçek atmaktadır. Bunu mahallenin kadınları kepazelik olarak algılar. Elenko veya Katinko adlı kadına gönül vermiştir. Ayrıca başka bir mavi gözlü kızla da ilişkisi olduğu ifade edilir. Muhlis’in sünnet düğününde kara gözlü kız istemesi de babasının bu gönül ilişkilerine bağlı olarak açıklanmaya çalışılır.

\section{Dil ve Üslûp}

Metnin dili genel olarak sade olmasına rağmen ağır ifadelerin de kullanıldığı dikkati çeker. Mehmet Asaf, bu metni oluştururken konuşma dilinin bütün imkânlarından faydalanır. Karşılıklı konuşmalara fazlaca yer vererek insanların birbirleri arasındaki sosyal ilişkileri açıklamaya çalışır (Çetin, 2005, s. 258). Metnin başında geçen "hanımne", "ayol” gibi ifadeler konuşma dilinin samimi hitap cümleleri kısmına örnektir. Bunlar haricinde genel olarak metin karşılıklı konuşmalar ve nesnel gözlemci anlatıcının olayı aktarması üzerinde şekillenir.

\section{Anlatım Teknikleri}

Mehmet Asaf'ın Bihter'le Muhlis adlı hikâyesinde anlatım tekniklerinden geriye dönüş tekniği, diyalog tekniği ve montaj tekniği kullanılır.

\section{Geriye Dönüş Tekniği}

Bu teknik hikâyenin sadece bir yerinde kullanılır. Muhlis'in babasının geçmişteki hayatı geriye dönüş tekniğiyle hatırlanır.

-A hanım, unuttunuz mu? Onun babası da küçüklüğ̈̈nde öyle idi. Elimde doğdu, büyüdü. Bilmez miyim hiç? On beşinde miydi; on altısında mı, işte o kadar bir şey...Yaptı̆̆ kepazelikler bütün mahallede çan çalınırdı. Tiyatrolara gidermiş de kantocu klzlara çiçek atarmış. Günahı üstünde kalsın. Benim neme lazım. Ben görmedim. Gördüm desem iki elim yanıma gelir. O zaman söylerlerdi. Geçmiş gün... Yirmi beş senelik bir şey.. Belki de otuz.. Büyük koleradan evvel miydi, sonra mıydı bilmem? Hocapaşa yangını o zaman galiba daha olmamıştı. O zamanın meşhur bir kokonası varmış. Elenko mudur, Katinko mudur? Nedir? Işste öyle bir kadın... Bu çocuğun babası, o vakit o kadını severmiş. Bizim rahmetli hacıdan da başka bir şey işitmiştim. Hacı bana bir gün dedi ki:

-Aman yahu, tirşe boyalı evin çocuğunu görme. Ben gördüm de parmağım ağzımda kaldı.

Ne olmuş ayol? 
dedim. Sonra bizim rahmetli birer birer anlattı. Çeşmenin üstündeki evin ortanca klzı bildiniz ya. Hani ya tenzifattaki kâtibin boşandı̆̆ı maviş gözlü kız... Canım bilmeyecek ne var? Daha geçen gece lakırdısı oldu idi de kırkını geçkindir diyorduk. Iş̧te o kızı severmiş. Ne diyecektim? Işste bu çocuk da babasına çekmiş. (s. 5-6).

Yukarıda alıntılanan bölümde Muhlis'in kara gözlü istemesi bağlamında çağrışım yöntemiyle babasının geçmişteki gönül ilişkileri hatırlanır ve geriye dönüş tekniğiyle sohbete konu olur.

\section{Diyalog Tekniği}

Roman ve hikâyenin temelinde yer alan diyalog yönteminden genel olarak bütün sanatçılar faydalanırlar. Diyalog yönteminin temel amacı farklı kişileri olaya dâhil etmek, anlatıma doğallık kazandırmak ve metnin ağırlı̆̆ını hafifletmektir (Tekin, 2003: 254-255). Mehmet Asaf'ın Bihter'le Muhlis adlı hikâyesinde genel olarak metne doğallık kazandırmak ve farklı kişileri olaya dâhil etmek maksadıyla diyalog tekniği kullanılmıştır.

- Şeker isterim hanımne!

- SSeker mi istedin; peki alalim benim bal yavrum!

- Bal isterim.

- Sen ağlama da bal aldırayım benim elmas çocuğum!

- Elmas isterim.

- Beybaban sana elmaslı saat de alacak benim kara gözlü evladım. (s. 4)

Yukarıda alıntılanan bölümde olay örgüsünün hafifletilmesi ve konuşma dilinin imkânlarından faydalanılarak anlatıma doğallık kazandırılmak istenir. Diğer diyalogların kullanıldığı yerlerde de yeni kişilerin metne dâhil edilmesi sağlanmıştır.

\section{Montaj / metinlerarası ilişkiler}

Montaj tekniği, romancının genel kültür bağlamında farklı bir metinden alıntıladığı bölümü eserinin içerisine katması veya kullanması demektir (Tekin, 2003, s. 243-244). Bu yöntemin bir diğer adı metinlerarası ilişkilerdir. İki veya daha çok metnin bir araya gelmesiyle oluşan metinlerarasılıkta bir metni başka metinler meydana getirir (Yalçın-Çelik, 2005, s. 47; Çetin, 2004, s. 9). Montaj tekniğinin eserin anlatımına katkı yapması ve zenginleştirmesi gerekir (Kolcu, 2005, s. 64).

Mehmet Asaf'ın Bihter'le Muhlis adlı hikâyesinde kolaj tekniğiyle bazı şiirlerin metnin içerisine dâhil edildiğini görmek mümkündür. Birçok yerde kolaj tekniğiyle şiirler metne dâhil edilmiştir. Bunlardan biri olan Yavuz Sultan Selim'in "felek" redifli eserini örnek olarak aliyoruz.

$$
\begin{aligned}
& \text { Merdüm-i dideme bilmem ne füsun etti felek } \\
& \text { Giryemi etti füsun eşkimi hûn etti felek } \\
& \text { Şîrler olurken pençe-i kahrımda lerzân } \\
& \text { Beni bir gözleri âhûya zebun etti felek (s. 15) }
\end{aligned}
$$

\section{İzlek}

Hikâye genel olarak aşk unsuru üzerine bina edilir. Ancak bunun yanı sıra âfetler, eşya, kalıtım, edebiyat ortamı, müzik konularına da değinilir. Hikâye genel olarak edebiyatın eski meselelerinden biri olan kavuşamayan iki kişi üzerine bina edilir. Fakat burada bir sınavdan geçme ya da birbirini arama söz konusu değildir. Tesadüf üzerine sünnet düğününde çocukken başlayan aşk öyküsü yine tesadüf üzerine Bihter'in evlendiğini Muhlis'in öğrenmesi üzerine son bulur. Bu birlikteliğe engel eskilerde olduğu gibi ne aile ne ekonomi ne de üçüncü kişilerdir. Tamamıyla Muhlis'in vazgeçişi ve bu aşkı kendi iç dünyasında öncelemeyişidir. Bu yönüyle 
kendisinden önce yazılmış olan diğer aşk hikâyelerinden ayrılır. Sekiz yaşında kara gözlü olarak nitelediği ve ailelerin de buna rıza gösterdiği aşka belki tek engel Bihter'in babasının Bursa'ya tayini üzerine uzaklıktır. Bu eski edebiyatta kavuşamamanın önünde bir engel teşkil etmez. Hatta bunun engel teşkil etmeyeceğini Şevket Muhlis'e anlatır. Şevket'in Bihter'le evlenmesini de üçüncü kişi olarak algılamamak gerekir. Çünkü uzun bir zaman geçtikten sonra Bihter Muhlis'ten herhangi bir haber alamayınca Şevket'le evlenmiştir. Aile noktasında da her iki aile daha çocukları küçükken ikisinin evlenmesini münasip görmüş, hatta nişan bile takmıştır. Bunların sonucu olarak ikisinin kavuşamamasının tek nedeni mekân değişimi ve Muhlis'in sevdiğinin peşinden gitmeyerek aşkı öncelemeyişidir.

Mehmet Asaf, Zavallı Baba adlı hikâyesinde olduğu gibi Bihter'le Muhlis adlı hikâyede de yaşanılan büyük olaylara atıfta bulunur. Hatta yaşı ı bayanların zamanı algılama biçimlerini de bu minvalde oluşturur. Buna göre 1865 yılında yaşanan Hocapaşa Yangını ve 1831'de başlayıp uzun yıllar devam eden kolera salgını metinde dikkat çekilen âfetlerdendir.

Özellikle Servet-i Fünûn romanlarında görülen eşya vasıtasıyla sevdiğini unutmama metaforuna burada da rastlanılır. Muhlis Bihter'den ayrılırken ona kendisini unutmaması için bir fotoğrafını verir. 18 yıl sonra da Bihter aynı fotoğrafı kendisine iade ederek onun masumane aşkını reddettiğini eşya vasıtasıyla ifade eder. Metnin Servet-i Fünûn özellikle Aşk-ı Memnu romanından tek farkı orada kadın eşyası aşk simgesi (Çetin, 2016, s. 93) olarak görülürken Bihter'le Muhlis adlı hikâyede erkek kadına fotoğrafını verir.

Naturalistlerin üzerinde durduğu kalıtım fenomeni yani davranışların da ebeveynden çocuğa intikal etmesi düşüncesi eserde dikkat çeken unsurlardandır. Buna göre naturalistlerin "Bu oylumlu yapıtta romancı birbirini izleyen beş kuşak boyunca kalıtımın ne denli etkili olduğunu ve içinde yaşadıkları koşulların bu soyun bireylerinde duygu, istek, dürtü, tutku ve benzeri her türlü doğal, içgüdüsel ve toplumsal davranışları nasıl etkilediğini göstermek istemiştir." (Sunel, 1981, s. 146) düşüncesi Bihter'le Muhlis adlı hikâyedeki Muhlis'in davranışlarını etkileyen unsurlardan birisi hâline dönüşür. Muhlis'in çocuk yaşta, sünnet düğününde kara gözlü isterim demesini ayıplayan kadınlar, bu anlayışın ona babasından geçtiğini ifade ederler. Babası Zekâi Bey'in on beş on altı yaşlarında kadınlarla iletişim kurması ve tiyatroda kadınlara gül atmasının sonucu olarak oğlunun da böyle olduğunu düşünürler. Söz konusu yaklaşım natüralistlerin neden sonuç ilişsisi ile kalıtım anlayışına yakınlık gösterir.

Eserde Muhlis vasıtasıyla Mehmet Asaf kendi edebiyat anlayışı, dolayısıyla o dönemdeki edebiyat ortamı hakkında bilgi verir. Buna göre Muhlis divan edebiyatı şairlerinden Nedim ve Fuzuli'yi; Muallim Naci ve onun devamı olan Nuri Şeyda, Andelib, Müstecabizade, Mehmet Celal ve Muhyiddin'i lezzetle okumaktadır. Mehmet Asaf, bu ifadelerle edebiyat açısından Muallim Naci taraftarı olduğunu hikâye kişisi tarafından beyan etmektedir.

Metnin üzerinde durduğu diğer izlek müzik kültürüdür. Muhlis ve ailesi Bihter'in evine gittiğinde "sûz-nâk" makamında Bihter onlara ut çalar ve gazel okur. Burada ev ortamındaki müzik sefaları dikkati çeker ve sosyal hayat içerisinde yer alan müzik kültürü dikkatlere sunulur. Diğer taraftan sosyal hayatta yer alan tiyatrolarda müzik kültürünün yaygın olduğu da vurgulanarak İstanbul'daki eğlence mekânları hakkında bilgi verilir. Muhlis'in babası tiyatrolara gitmekte ve burada kantocu kızlara gül atmaktadır. Bu vesileyle hem müzik kültürü hem de İstanbul'daki eğlence hayatı hakkında bilgi verilir.

\section{Sonuç}

Mehmet Asaf' ın Bihter'le Muhlis adlı hikâyesi Bihter ile Muhlis'in çocuklukta başlayan aşk maceralarını konu alır. Bihter'in ailesinin İstanbul'dan ayrılması üzerine iki gencin aşkları evlilik ile sonuçlanamaz ve Bihter Muhlis'in en yakın arkadaşı Şevket ile evlenir. Olay örgüsünün kısaca bu şekilde ilerlediği metinde sekiz metin vaka birimi mevcuttur. Bu vaka 
birimleri düz bir çizgi şeklinde ilerler ve merak unsuru sadece metnin sonuç kısmında kendine yer bulur. Metinde "nesnel tutumlu gözlemci anlatıcı" kullanılır. Anlatıcı olaylara müdahale etmez, yorumlamaz ve sadece gördüklerini okuyucuya tasvir etmekle yetinir.

Eserde mekân unsuru genellikle açık mekânlar çevresinde vücut bulur. Kapalı mekân olarak Muhlis'in evi, Bihter'in İstanbul'daki evi ve Bihter'in Bursa'daki evi yer almasına rağmen söz konusu yerler sadece isim olarak kullanılıp haklarında okuyucuya bilgi verilmez. Açık mekân genel olarak İstanbul'dur. İstanbul'un çeşitli semtleri eser içerisine serpiştirilerek şehir tanıtılmaya çalışılır. Diğer açık mekân ise, Bursa'dır. Bursa'ya yolculuk ve Bursa'nın kaplıcaları eserde vurgulanan hususlardır. Konya ve İzmir de Şevket'in tayin oldukları yerler olması sebebiyle metinde sadece isim olarak geçen yerlerdir. Metnin nesnel zamanı 1890'larda başlayıp 1910'lara kadar sürer. Zaman unsuru ile ilgili metinde net bir bilgi olmayıp kolera salgını ve Hocapaşa Yangını dolayısıyla metnin zamanı gösterilmeye çalıșılır. Eser Bihter ile Muhlis' in çocukluklarından başlayarak ilerlediği için biyografik bilgiye bağlı olarak zamanın kullanıldığı görülür; metin de baştan başlayarak vücut bulduğu için klasik hikâye formuna uygundur. Diğer taraftan hikâyenin bazı bölümlerinde net bir tarih verilmekten kaçınıldığı görülür.

Hikâyenin kişiler kadrosu geniş olsa da haklarında bilgi verilen kişi sayısı azdır. Buna göre Muhlis, entelektüel, edebiyata meraklı, aşkının peşinden koşmayan bir kişilik özelliği çizer. Bihter de entelektüel, edebiyat ve müziğe meraklı, aşkından vazgeçmeyen, uzun yıllar Muhlis'i bekleyen, ancak o gelmeyince evlenen bir kişidir. Muhlis'in babası hakkında bilgi verilen diğer kişidir. Gençliğinde hovardalık yapan, yabancı bayanlarla gönül eğlendiren bir yapıya sahiptir. Bunların dışında fon karakterler oldukça fazladır. Sünnet dügünü merasimi vesilesiyle birçok kiși olaya dâhil olur. Ancak bunlar içerisinde Bihter'le evlenen ve Muhlis'in en yakın arkadaşı olan Şevket, Muhlis'in dert ortağı olması ve Bihter'le evlenmesi dolayısıyla hakkında diğer fon karakterlere göre daha fazla bilgi verilen kişilerdendir. Metnin dili bazı yerlerde sade, bazı yerlerde ise oldukça ağdalıdır. Eserde anlatım tekniklerinden diyalog, geriye dönüş tekniği ve montaj tekniği kullanılır.

Metinde kullanılan izleklerden ilki aşktır. Kavuşamayan âşık imgelemi Türk edebiyatını uzun yıllar etkilemiş olmasına rağmen hikâyedeki birleşememe unsurunun temel sebebi âşık gençlerden birisinin sevdiğinin peşinden gitmemesidir. Aileler bu konuda oldukça 1lımlı, hatta bu evliliği destekleyen bir yapıdadır. Bundan dolayı söz konusu iki gencin evlenmeleri için önlerinde bir engel yoktur. Sadece tek engel Bihter'in babasının tayini dolayısıyla Bursa'ya gitmiş olmasıdır. Ancak bunun engel olmadığı Muhlis'in Şevket'le olan konuşmasında yazar tarafından gün yüzüne çıkarılır. Eserin diğer izleği âfettir. Hocapaşa Yangını ve Büyük Kolera Salgını eser kişilerinden birisinin zamanı algılaması dolayısıyla esere dâhil olur. Sevdiğinden bir nişan olarak eşyanın kullanımına, Bihter giderken Muhlis'in ona verdiği fotoğrafla göndermede bulunulur. Kalıtım izleği, Muhlis'in çocukken kara gözlü istemesinin sebebi olarak babasının hovardalıklarının örneklendirilmesiyle gün yüzüne çıkar. Edebiyata meraklı olan Muhlis, yazarın yazına bakış açısını vermesi ve edebiyat ortamını anlatması bakımından önem taşır. Buna göre, Muhlis Fuzuli, Nedim ve Muallim Naci ile onun devamını lezzetle okumaktadır. Bütün eserlerinde bir şekilde müzik bahsi açan Mehmet Asaf, Bihter'le Muhlis hikâyesinde de Bihter'in sûz-nâk makamında ut çalmasına göndermede bulunur.

Sonuç olarak, Bihter'le Muhlis hikâyesi iki gencin uzaklık yönüyle birbiriyle evlenememeleri, edebiyat ortamı, âfetler, kalıtım unsuru, müzik zevki ve İstanbul'un yaşam şartları üzerine bina edilmiş bir metindir. 


\section{BİHTER'LE MUHLİS}

\section{Küçük Hikâye}

\section{Sahip ve Nâşiri:}

\section{Kütüphane-i Sudi}

\section{İstanbul - Babıali Caddesi Numara 40}

\section{(2) BİHTER'LE MUHLİS}

Evin içi kalabalık mı kalabalık...Sinekli Bakkal'dan halası, Çapa Çeşmesi'nden teyzesi, Gedikpaşa'dan büyük ablası, Kabasakal'dan anneannesi, Zirek'ten ebesi, Kara Gümrük'ten eski aşçı kadın, Yeni Bahçe'den kahveciye verdikleri besleme, Kırkçeşme'den komşunun azatlısı Tarandil bugün hep buraya toplanmışlar...

Bunlara Muhasebecilerin hanımı iki kızıyla, Alperdelilerin hanımı beş yaşındaki torunuyla, Defterdarların gelinini iki çocuğu bir hizmetçisiyle, Yağlıkçıların kaynanasını kız kardeşiyle, Mısırçarşılıların annesini gelini ile, yandaki, karşıdaki, alt ve üst taraftaki komşuları, uzaktan yakından, Boğaziçi'nden, Kadıköy ve Haydarpaşa'dan gelenleri bütün büyügüu, küçügü, ortancası, çocuğu, görümcesi, kaynanası, baldızı, kızı, torunu, hizmetçisi, beslemesi ile ilave edecek (3) olursanız evin ne derecede izdiham içinde olduğu derhâl tezahür eder. Gürültü, patırtı mı dediniz? Haddi, hesabı yok. Sadanın, zırıltının, vızıltının enva1:

- Anne ben de oyuncak isterim.

- Burada rahat durursan yarın sana da öyle yelkenli kayık alırım. 
- Hanımne! alacağım!

خانمن On para ver! Kapının önünde şekerci duruyor. Latilokum

- Gözü kör olası yumurcak! Şimdi sakızleblebisi yedin! Aman Allah ne pis boğazlık bu!

- Hanımne! Hokkabaz nerede?

Bir aralık def gürültüleri;

Cif caf caf cif caf

- Ama benim pehlivanım!

- Buyur ustacı̆̆ım!

Bu sırada sünnet çocuğunda zırıltı:

- Hanımne! Hanımneciğim! Acıyor hanımına acıyor!

Hanımnesi karyoladaki mavi takyeli toramanın boynuna sarılarak ve yanaklarından şap şap öperek:

- Hanımnesinin kuzusu benim güzel yavrum! Benim güzel şeker evladım!

(4) Çocuk huysuzlanarak:

- Şeker isterim hanımne!

- Şeker mi istedin; peki alalım benim bal yavrum!

- Bal isterim.

- Sen ağlama da bal aldırayım benim elmas çocuğum!

- Elmas isterim.

- Beybaban sana elmaslı saat de alacak benim kara gözlü evladım.

Çocuk hâlâ ağlayarak:

- Kara gözlü isterim hanımne.

Sünnet çocuğunun kara gözlü isterim diye zırladığını işiten hanımlardan birkaçı yavaş yavaş konuşmaya başlarlar:

- İşitiyor musun Huriye Hanım. Oğlan kara gözlü isterim diye zırlıyor. Rabbim göstermesin. Bütün bunlar kıyamet alameti.

- Ayol dokuz yaşındaki çocukların kara gözlüden anladığını da şimdi işittim. Tü, tü! Üstüme iyilik sağlık... Daha, daha bakalım neler göreceğiz.

Söz söyleyen hanımın sözünü bir diğer hanım keserek:

- A hanım, unuttunuz mu? Onun babası da küçüklüğünde öyle idi. Elimde doğdu, büyüdü. Bilmez miyim hiç? (5) On beşinde miydi; on altısında mı, işte o kadar bir şey...Yaptığı kepazelikler bütün mahallede çan çalınırdı. Tiyatrolara gidermiş de kantocu kızlara çiçek atarmış. Günahı üstünde kalsın. Benim neme lazım. Ben görmedim. Gördüm desem iki elim yanıma gelir. $\mathrm{O}$ zaman söylerlerdi. Geçmiş gün... Yirmi beş senelik bir şey.. Belki de otuz.. Büyük koleradan evvel miydi, sonra mıydı bilmem? Hocapaşa yangını o zaman galiba daha olmamıştı. O zamanın meşhur bir kokonası varmış. Elenko mudur, Katinko mudur? Nedir? İşte öyle bir kadın... Bu çocuğun babası, o vakit o kadını severmiş. Bizim rahmetli hacıdan da başka bir şey işitmiştim. Hacı bana bir gün dedi ki:

- Aman yahu, tirşe boyalı evin çocuğunu görme. Ben gördüm de parmağım ağzımda kald1. 
Ne olmuş ayol?

dedim. Sonra bizim rahmetli birer birer anlattı. Çeşmenin üstündeki evin ortanca kızı bildiniz ya. Hani ya tenzifattaki kâtibin boşandığı maviş gözlü kız... Canım bilmeyecek ne var? Daha geçen gece lakırdısı oldu idi de kırkını geçkindir diyorduk. İşte (6) o kızı severmiş. $\mathrm{Ne}$ diyecektim? İşte bu çocuk da babasına çekmiş.

- Ne olacak zamane evlatları hanım?

Karyoladan bu sirada yine bir zırılt1:

Hanımneciğim, hanımneciğim.

Büyük hanım; hafidinin yine alnına, yanaklarına tükürüklü, şapırtılı buseler kondurarak:

- Ağlama benim güzel yavrum ağlama.

Çocuğun bu zırıltısından, şımarıklığından annesinin canı sıkılır. Kayınvalidesine hitaben:

- Darılmayınız ama hanımne hep kabahat sizde... Bu oğlana bu kadar yüz verilir mi?

Büyük hanım, gelinine hiddetlenir. Açar ağzını, yumar gözünü:

- Ne olacak zamane kızları... Yalnız böyle doğurmasını bilirler. Çocuk oyalamasını bilmezler ki..

Sünnet çocuğu yine ağlamakta, haykırmakta devam eder:

- Hanımneciğim, hanımneciğim.

Büyük hanım; yine torununun boynuna sarılıp bir mutat şapırtılı bir surette öptükten sonra:

- Karnın acıktı mı yavrum? Külbastı getireyim yer misin çocuğum.

- (7) Külbast1 yemem.

- Çorba...

- Çorba da istemem.

- Muhallebi..

- Tavuk söğüşü var. Onu da yemez misin?

- İstemem...

- Ne istersin a benim kara gözlü tombul evladım.

- Kara gözlü isterim.

Büyük hanım şaşırarak:

- Kara gözlü nedir? Kara gözlü kuzu mu istersin?

- Kuzu istemem.

- Ya kara gözlü nedir?

Çocuğun karyolası etrafında birkaç çocuk oturuyor, hokkabazın yeniden cif cafa başlamasına intizar ediyorlardı.

$\mathrm{Bu}$ çocukların arasında henüz altı yaşlarında bir kızcağız vardı ki pek şirin, pek güzel idi. Karyoladaki toraman bu pek can-rüba kızcağızı işaret ederek:

- Bunu isterim.

dedi. Büyük hanım şaşırdı:

- (8) A, a, a. 
dedi(. Y.N.) Bütün hanımlar gülüştüler. Bunun üzerine büyük hanım:

- İnşallah; dedi; ikisi de büyüsün de Muhlis'e Bihter'i alırız.

Bihter'in validesi de memnunane:

- İnşallah, inşallah. O günü görelim de... diye cevap verdi.

\section{2}

Henüz sekizini bitirmiş, dokuzuna basmış olan Muhlis'le Bihter; böyle ufak bir sözle sünnet dügünü gününde nişanlanmışlardı. Hatta bu nişan keyfiyeti Bihter, babası Arif Bey ile Muhlis'in pederi Zekâi Efendi arasında da konuşuldu. Onlar da:

- İnşallah o güne gelelim de...

diye iși istikbale talik ettiler.

Artık günler süratle geçiyor, iki çocuğun da sinni ilerliyordu.

(9) Muhlis, on üç yaşında iken rüştiyeyi ikmal ederek idadiye geçmiş, Bihter de okuduğunu anlar bir dereceyi bulmuştu.

İki aile arasında son derece bir muhabbet, samimi bir münasebet mevcut olduğundan Muhlis'le Bihter birbirlerini hemen her gün, her gece görürler, konuşurlardı.

Daha on dört yaşına reşide olduğu sıralarda Muhlis'te şiire bir incizap hasıl olmuştu. Bu incizap onu tahsil-i edebiyata sevk etti. Kavaid-i edebiyeyi okudu, aruzu ezberledi. Üdeba ve şuara-yı sâlifeden pek çoklarını nakş-1 hafıza kıldı.

Muhlis; Nedim'i Fuzûli'yi pek seviyordu. Fakat onun incizâb-1 fevkaladesi Naci merhuma idi. Muallim Naci'yi ve ve onun mektebinde yetişen Nuri Şeydaları, Andelibleri, Müstecabizadeleri, Mehmed Celalleri, Muhyiddinleri büyük bir lezzetle okuyor, onların bir gazelini bin şiir-i dil-ârâma tercih ediyordu.

Bihter'de de şiire heves vardı. O da bir şiir okunurken mest-i huzûz oluyor, hatta kendisi de bir şeyler söylemek istiyor, fakat fikdân-1 tahsili, noksan-1 tetebbu buna mâni oluyordu. (10) Kızının şiire olan meyelânını hisseden ve Muhlis'in de vadi-i edebiyatta terakki etmekte olduğunu bilen Bihter'in pederi bir gün Muhlis'in babasına:

- Bizim kızda görüyorum ki şiire karşı büyük bir meyelân var. Vakti boş olduğu bazı geceler Muhlis Bey biraz kavaid-i edebiyeyi gösterirse Bihter'in istidadı inkişaf eder.

Muhlis'in pederi hemen muvafakat etti:

- Hakikaten münasip!

dedi.

sonra Muhlislerin evinde iki aile erkânı kavaid-i

Edebiyeyi göstermeye

Hemen sene kadar haftada üç dört gece derse devam üslub-1 meziyetin ne demek olduğunu pek ulviyet-i hissini, ulviyet-i fikrini, ulviyet-i hayali takdir ediyor, yazılarında tenafürden, kesret-i tekrardan zayıf teliften içtinap eyliyordu. ${ }^{2}$

2 olan yerler metinde silik çıktığı için okunamamışıtır. Metnin farklı nüshaları da bu meyanda karşılaştırılmıştır. Onların da aynı bölümlerinin silik olduğu görülmüştür. 
Bir gece, yine aile erkânı oturup dereden tepeden konuşurlarken Bihter Muhlis'in odasında Mehmet Celal'in bir şiirini okuyorlardı.

(11) Bihter dedi ki:

- Geçen akşam okuduğumuz şiiri pek beğenmiştiniz değil mi?

Muhlis sordu:

- Hangi şiirdi o?

- “Zülf”' sernameli şiir... Ne çabuk unuttunuz?

- Evet; evet; pek güzeldi. Oku! Bir kere daha oku; oku Bihter.

Bihter kitabın o sahifesini çevirdi. Okumaya başladı:

Âş1k olmuşken melekler ey perîşân, zülfüne.

Düşmesin mi söyle inşanlar perişân zülfüne?

Kâkülünde şâna kalmış sanma ey hûrşîd-rû.

Çâk çâk olmuş asılmış kalb-i sûzân zülfüne

Hiddet-âver bir nigâh ile semâvî gözlerin

Nûr-1 dîdem; ben senin oldumdu hayrân zülfüne

Aks-i nûr hüsnünü zülfünde gördüm ey mülk

Şû‘le efşân oldu sandım mihr-i tâbân zülfüne

(12) Muhlis:

- Bir şiir daha vardı ki onu da pek sevmiştim.

- Bihter sordu:

- Hangisi idi o?

Muhlis; iki dakika düşündü. Sonra her nedense o şiiri okutmaktan vazgeçti. Dedi ki:

- Bihter! Dün gece bir şiir, bir feryat yazdım. İster misin okuyalım!

Bihter birdenbire şaşırdı. Reh-i gülgûnundan hafif bir humret [kırmızılık, kızıllık] hasıl oldu. Fakat itidalini muhafaza etti:

- Okuyunuz:

dedi. Muhlis cebinden ufak bir kâğıt çıkardı. Feryat dediği şiirini titrek bir sesle okumaya başladı:

Semâ-yı kalbime sen ey perî-i hüsn ü cemâl

Tulû'u mâh-1 cemâlinle lem'a bâr oldun;

Neşîdelerle, şiirlerle neşe-bâr oldun;

Açıldı pîş-i nigâhımda ufk-1 şiir ü hayâl 
(13) Tahayyül eyliyorum şimdi hep leyâlimde

Kamerli bir gece, bir leyl-i hande-rîz-i bahâr

Semâs1, bahr-i dilârâsı, sâhili nevvâr

Uzakta bir dere, bir cûy-bâr-1 neşe-fezâ

Bu yanda güllerin üstünde bir küçük bülbül

Dikip dü-çeşmini nilgûn-1 semâya; girye-fezâ

Öterken ey bana ilhâm-1 şiir eden şûh gül

Ben öyle istiyorum ki şu hâl-i zârımda

Bu leyl-i mukmirin âgûş-1 dil-nüvâzında

O cûy-bâr-1 latifin kenâr-1 misâkında

Elin elimde, gözün çeşm-i girye-bârımda

Latîf nağme-i leyli bu hâlde gûş etmek

Lebin lebimde semâvi nigâh mestinde

Esîr-i ruhunu ruhumla mass u nûş etmek

- Nas1l; dedi, beğendin mi?

(14) Bihter cevap verdi:

- Çok güzel...

Bu esnada içeriki odadan bir ses, Bihter'in validesinin sesi aksetti:

- Bihter, biraz ut çalsana.

Bihter haykırdı:

- Peki anneciğim.

Ve Muhlis'e sordu:

- Ne çalayım?

Muhlis:

- Sûz-nâk.

dedi. Bihter; latif bir taksimden sonra başladı:

Sûz-nâk etme beni ey mehveşim

Așk ile zaten mücessem âteșim

Dert ocağıdır dil-i mihnet-keşim

Aşk ile zaten mücessem âteşim 
Bihter'in nazik, latif sesine Muhlis'in sadası da karışmış idi. Bu güzide şarkıyı ikisi birden okuyorlard1.

(15) İçeriki odadan bu defa da Muhlis'in validesi seslendi:

- Muhlis; dedi; arada bir gazel yok mu?

Muhlis cevap verdi:

- Peki.

Şimdi mızrap; utun telleri üstünde ihtizâz ederken Muhlis okumaya başlamıştı:

Merdüm-i dideme bilmem ne füsun etti felek

Giryemi etti füsun eşkimi hûn etti felek

Şîrler olurken pençe-i kahrımda lerzân

Beni bir gözleri âhûya zebun etti felek

Genç çocuk bu son misraı girye-nâk, mühtezz [ihtizaz eden, titreyen; sevinçten oynayan] bir sesle okumuş, zavallı Muhlis'in gözlerinden dökülen katreleri Bihter görmüştü. Saf kız bilâ-ihtiyar yavaşça sordu:

- Ne oldu? Niçin ağlıyorsunuz Muhlis Bey lakayidane:

Muhlis bir dakika düşündü. Ne cevap vermek lazım geleceğinde izhar-1 aciz etti. Sonra

- Hiç.

dedi. Bihter; büyük bir endişe ile tekrar etti:

- (16) Niçin ağlıyorsunuz? Bu gözyaşları sebepsiz olur mu?

- Bedbaht olacağımı anlıyorum da onun için...

$\mathrm{Bu}$ geceden sonra hemen bir hafta kadar Muhlis'le Bihter birbirlerini görmemişlerdi. Bir hafta, belki on gün sonra bir gece yine ailesiyle beraber Muhlislerin evine gelen Bihter; gayet endişeli bir tavır ile:

- Muhlis; dedi, artık birbirimizi görmeyeceğiz, ayrılıyoruz.

Muhlis evvela alay etmek istedi:

- Küçük hanımefendi öyle mi arzu ediyorlar?,

dedi. Bihter evvelkinden daha endişeli bir nazarlarla Muhlis'in yüzüne bakarak:

- Alay değil Muhlis; dedi, ciddi söylüyorum.

Muhlis biraz şaşırdı:

- (17) Ne demek istediğini anlayamıorum.

dedi.

- Belki bir haftaya kadar hareket ediyoruz.

- Nereye?

- Bursa'ya...

- Tebdil-i hava için mi? 
- Hayir... Pederim orada bir memuriyete tayin edildi.

- Ya, demek bir hafta sonra.....

Muhlis bundan ötesini söylemeye muktedir olamadı. Çünkü gözleri dolmuş, boğazına bir şey tıkanmıştı. Bihter'in de güzel gözlerinden inci taneleri dökülüyordu.

Bihter ve ailesi bu gece Muhlislerin evine vedaya gelmişlerdi. Artık yarın sabah hareketleri mukarrer idi. Bihter yine Muhlis'in odasına gitti.

İkisi de derin bir sükût içinde düşünüyorlardı. Bu (18) sükûtu içeriki odadan akseden bir ses ihlal etti. Bihter'in validesi.

- Bihter; diyordu; bu gece son defa olarak ut çalmaz mısın?

Bihter cevap verdi.

- Peki efendim.

Mızrap titredi. Ut inlemeye başladı. Muhlis; gözyaşları içinde dedi ki.

- Bihter; bir şarkı çal ki tercüman-1 kalbim olsun.

Bihter.

- Yalnız senin değil; ikimizin de tercüman-1 his ve kalbi olsun.

diye cevap verdi. Söylemeye başladı.

Mehd içinde eşk-i mihnetle açılmış gözlerim

Görmedim hiçbir güzel gün ağlamaz da neylerim

Hâlet-i nez'a gelirsem belki hande eylerim

Görmedim hiçbir güzel gün ağlamaz da neylerim

Birkaç şarkı daha çaldılar. Arada Muhlis bir gazel okudu. (19) Artık vakit gecikmişti. Ayrılacakları sırada Muhlis Bihter'e bir şey verdi.

- Sana yadigârım olsun. Baktıkça beni hatırlarsın

dedi. Bihter'in derhâl koynuna soktuğu bu yadigâr Muhlis'in mahzunane bir vaziyette alınmış fotoğrafıydı.

Ertesi sabah erkenden Muhlis; peder ve validesiyle beraber Galata rihtımında idiler. Vapurun hareketine bir saatten fazla var idi.

Yolcular girip çıkıyor, hamallar eşya naklediyorlardı. Vapurun hareketine yarım saat kala gelen Bihter ile ailesi, Muhlis ve pederiyle validesini rıhtımda buldular. Hepsi birden vapura girdiler. Eşyalar yerli yerine konuldu. Artık vapur; hareket edeceğini bir düdük ile işaret etmişti. Çıpalar, halatlar alındığı sıralarda Muhlis'le ailesi çıktılar. Beş dakika sonra da vapur hareket etti.

(20) Muhlis'in bugün mektebe mikadından iki saat kadar sonra geldiğini gören pek samimi refiki Şevket sordu: 
- Muhlis! Niçin bu kadar geç kaldın?

Muhlis; Bihter'le olan münasebetlerini daha evvelce bu müşfik arkadaşına açmıştı. Bu defa da meseleyi anlattı. Şevket gülerek:

- Allah kavuştursun!

dedi. Muhlis'in fevkalade endişeli olduğunu görerek ilave etti:

- Birader! O kadar niçin müteessir oluyorsun? Bursa dediğin neresi? İstanbul'un bir mahallesi... Dört saatte buradan Mudanya... İki saat kadar da tren... Hepsi alt1 saat... Zikzak vapurla Sarıyer'e gider gibi... Hem meşhur bir söz vardır. Dağ dağa kavuşmaz insan insana kavuşur derler. Haydi yavrum! Müteessir olma öyle...

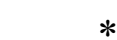

(21) Muhlis'le Şevket tahsil ettikleri mekteb-i âliyi üç sene sonra ikmal ettikleri zaman Şevket; Bursa' da bir memuriyete tayin edilmiş, Muhlis de İstanbul'da âlem-i şiir ve edebiyata atılmıştı.

On beş sene sonra ehemmiyetsiz bir hastalık; Muhlis'i biraz düçar ve zayıf etmiști. Doktorlar tebdil-i hava için Bursa'yı, Bursa'nın kaplıcalarını tavsiye eylediler. Mevsim; bahar idi. Nisan evâhiri...

Bir sabah Galata rıhtımından erkenden bindiği bir vapur dört buçuk saat sonra Mudanya'ya çıkardı oradan trene atıldı.

Muhlis; Çekirge'ye gidecek, kırk gün kadar orada güzel bir otelde oturacak, kaplıcalara girecekti. Tren hareket etti her iki tarafına zeytin ağaçları dikilmiş olan yol; Muhlis'in pek hoşuna gitmişti. Kendi kendine:

- Bu yol ne güzel... Bursa kim bilir daha ne kadar güzeldir.

(22) diyordu. Ta çocukluğundan beri methini işittiği Bursa için Muhlis’te âdeta bir iştiyak vardı. Tren yaklaştıkça bu iştiyak artıyordu. Nihayet Çekirge'nin istasyonu olan "Acemler İstasyonu"nda tren durdu. Birçok yolcu ile beraber Muhlis de indi. Küçük bavulunu bir arabaya koymak üzere iken arkasından bir ses aksetti:

- Muhlis Beyefendi! Bizi haberdar etmeden Bursa’ya gelmek nasıl olur?

Muhlis başını çevirdiği zaman Şevket'i, on sekiz sene evvel mektepte okudukları eski arkadaşı Şevket'i gördü:

- Vay Şevketçiğim! dedi; sen buradasın ha; Şevket cevap verdi:

- Buradayım ya! Mektepten çıktığım zaman ilk memuriyetim Bursa'da idi. Sonra

İzmir'e, daha sonra da Konya'ya tayin olunmuştum. Fakat felek bana yine burasını, bu güzel memleketi nasip etti. Yedi aydan beri buradayım. Ey! Söyle bakalım. Sen de memura mı geldin?

- Hayır birader. Biraz rahatsız idim. Kaplıcalara girmek için geldim. Şöyle kırk gün kadar...

- Ne iyi olmuş. Ben bugün biraz gezmek için istasyona (23) ineyim; dedim, geldim. Meğer bir hiss-i kablelvuku beni buraya sevk etmiş. Haydi gidelim. 
Muhlis sordu:

- Nereye?

- Bizim eve...

- Lakin rica ederim Şevket. Beni bırak otele gideyim. Çünkü uzun müddet kalacağım.

- Bizim evde de uzun müddet kalabilirsin. Fakat rahatsız olurum dersen hiç olmazsa iki gece... Münasip bir otel buluncaya kadar...

- Sen de Çekirge'desin öyle mi?

- Evet... Esplandid (Splendid Y.N.) oteline yakın...

İstasyonda bindikleri araba bir çar-yek sonra iki arkadaşı Şevket'in hanesine isal etti. Kapıyı kara gözlü, kara kaşı, on iki yaşında bir kızcağız açtı. Şevket:

- Sara; dedi; öp amca beyin elini.

Muhlis; ellerini öpen bu ipek gibi yavrucağın simasında başka bir çehre, eskiden beri aşina olduğu bir çehre gördü.

Mütereddidane düşünürken Şevket ilave etti.

- (24) Muhlis; dedi; bu benim kızım Sara... Annesinin çocukluğuna benzettin değil mi?

Muhlis, derhal intikal etti. Şevket sözünde devam ediyordu.

- Mektepten çıktığım zaman bilirsin ya ilk memuriyetim Bursa idi. Bihter'in merhum pederi de o zaman burada memuren bulunuyordu. İşte Bihter bana kısmet oldu. $\mathrm{Ne}$ denir? Kader kısmet değil mi?

Muhlis, süzgün gözlü, baygın bakışlı Sara'nın saçlarını okşarken bu izdivacı Şevket'e tebrik etti.

Muhlis sabahleyin yastığının üstünde rengi değișmiş, eskimiş bir resim buldu. Dikkat etti. Kendisi idi. On sekiz sene evvel Bihter Bursa'ya gelirken "Beni unutmazsın" diye verdiği fotoğraf... O eski fotoğraf...

Muhlis'in on sekiz sene evvel gözyaşlarıyla beslediği aşk-1 masumanesi on sekiz sene sonra işte böyle iade olunmuş, reddedilmişti.

\section{SON}

\section{Kaynakça}

Aktaş, Ş., (2015). Anlatma esasına bağlı edebî metinlerin tahlili, Ankara: Kurgan Edebiyat Yayınlar1.

Borsac1, M. A., Bihter'le Muhlis, İstanbul: Kütüphane-i Sudi.

Cunbur, M., (2002). Borsac1, Mehmet Asaf, Türk Dünyası Ortak Edebiyatı Türk Dünyası Edebiyatçıları Ansiklopedisi. , C. 2. s. 316-317.

Çapanoğlu, M. S., (1961). Seksen yıllık gazetecimiz Âsaf Konsilitçi. İstanbul: Sinan Matbaas1. Çetişli, İ., (2004). Metin tahlillerine giriş / 2. Ankara: Akçă̆ Yayınları.

Çetin, N., (2004). Yeni Türk şiirinde geleneğin izleri, Ankara: Hece Yayınları.

Çetin, N., (2005). Roman çözümleme yöntemi, Ankara: Öncü Kitap Yayınları.

Çetin, N., (2016). İkinci Abdülhamit dönemi Türk edebiyatı, Ankara: Nobel Yayınları.

Çetin, N., (2017). Türk hikâyesi tahlilleri, Ankara: Nobel Yayınları.

Gürses Söğüt, S., (2019 Mart-Nisan). Modern bir imari çözümleme denemesi: 1865 Hocapaşa yangın1, Mimarlık. 406: 54-59. 
Işık, İ., (2007). Resimli ve metin örnekli Türkiye edebiyatçılar ve kültür adamları ansiklopedisi. (2. Cilt). Ankara: Elvan Yayınları.

İnuğur, M. N., (1999). Türk basınında “iz” birakanlar, İstanbul: Der Yayınları.

Kolcu, A. İ., (2005). Öykü sanatı, Ankara: Salkımsöğüt Yayınları.

Özdemir, S., (2019). XIX. Yüzyılda Kastamonu Vilayeti'nde salgın hastalıklar, Yayınlanmamış Yüksek Lisans Tezi, Kastamonu.

Soğukömeroğulları, M., (2019). Mehmet Asaf Borsacı. Türk Edebiyatı İsimler Sözlüğü.

Sunel, A. H., (1981 Ocak). Doğalc1lık. Türk Dili. 349, 139-147.

Tekin, M., (2003). Roman sanatı, İstanbul: Ötüken Yayınları.

Yalçın-Çelik, D., (2005). Yeni tarihselcilik kuramı ve Türk edebiyatında postmodern tarih romanları. Ankara: Akçağ Yayınları. 